\title{
Kurumsal Kimliğinin Oluşturulması Sürecinde Web Siteleri: Konya'daki Şirketler Üzerine Bir Değerlendirme
}

\author{
Websites in the Process of Creating Corporate Identity: An Evaluation on Companies in Konya \\ Birol Büyükdoğan, Dr. Öğr. Üyesi, KTO Karatay Üniversitesi Sosyal ve Beşeri Bilimler Fakültesi, \\ E-posta: birol.buyukdogan@karatay.edu.tr \\ Bülent Bingöl, Dr. Öğr. Üyesi, KTO Karatay Üniversitesi Sosyal ve Beşeri Bilimler Fakültesi, \\ E-posta: bulent.bingol@karatay.edu.tr
}

https://doi.org/10.47998/ikad.839117

\begin{abstract}
Anahtar Kelimeler:
Kurumsal Kimlik, Web Siteleri, Kurumsal Tasarım, Kurumsal Kültür, Kurumsal İletişim, Kurumsal Davranıș.
\end{abstract}

\section{$\ddot{O} z$}

Kurumsal imaj ve kurumsal itibarın sağlanmasında kurumsal kimlik çok önemli bir yer işgal etmektedir. Kurumsal kimlik, şirketlerin kendilerini nasıl gördüğüne ilişkin bir kavramdır. Bu kavramdan hem fiziki alanda hem de dijital alanda söz etmek mümkündür. Kurumsal kimlik daha çok kurumsal tasarım, kurumsal kültür, kurumsal davranış, kurumsal iletişim ve kurumsal yapı başlıkları altında incelenmektedir. Dünyadaki dijital dönüşümle birlikte kurumsal kimlik kurumsal web sitelerine taşınmış ve kurumsal imaj açısından çok büyük avantajlar sağlamıştır. Çalışmanın amacı şirketlerin kurumsal web sitelerinde kurumsal kimliklerini nasıl yansıttıklarını değerlendirmektir. Çalışmanın örneklemi İSO'nun (İstanbul Sanayi Odası) 2019 ilk ve ikinci 500 listesinde olan Konya'daki şirketlerdir. Çalışmada söz konusu listede yer alan 22 şirketin web siteleri kurumsal kimliğin alt unsurlarına göre analiz edilmiştir. Çalışma 1-30 Kasım 2020 tarihleri arasında gerçekleştirilmiştir. Çalışmaya göre; şirketlerin ancak yarısının web sitelerinde kurumsal kimliğin beş unsuruna tamamen yer verdikleri görülmüştür. Çalışmada kurumsal kültür en fazla yer verilen kurumsal kimlik unsuru olurken, kurumsal yapı ise en az yer verilen unsurdur. Şirket web siteleri daha çok pazarlama ve satış amaçlı olarak kullanılmıştır. Web sitelerinde kurumsal imaja etki edecek sosyal sorumluluk ve sponsorluk gibi faaliyetlere ise çok az yer verilmiştir.

Keywords:

Corporate Identity, Corporate Websites, Corporate Culture, Corporate Communication, Corporate Behavior.

\section{Abstract}

Corporate identity occupies a very important place in ensuring corporate image and corporate reputation. Corporate identity is a concept about how companies see themselves. This concept can be mentioned in both the physics field and the digital field. Corporate identity is mostly examined under the heading of corporate design, corporate culture, corporate behavior, corporate communication, and corporate structure. With the digital transformation in the world, corporate identity has been moved to corporate websites and has provided great advantages in terms of corporate image. The purpose of the study is to evaluate how companies reflect their corporate identity on corporate websites. The sample of the study is the companies in Konya that are in the first and second 500 lists of ISO (Istanbul Chamber of Industry). In the study, the websites of 22 companies in the list are analyzed according to sub-elements of corporate identity. The study was conducted between 1-30 November 2020. According to study, it has been observed that only half of the companies completely include five elements of corporate identity on their websites. While corporate culture is the most frequently used elements of corporate identity in the study, corporate structure is the least-mentioned element. Company websites are used mostly for marketing and sales. Activities such as social responsibility and sponsorship that affect the corporate image are rarely included on the web sites. 


\section{Giriş}

Küreselleşen dünyada ürün ve kuruluşların birbirine benzemeye başlamasıyla birlikte, müşteri için ayırt edici başka unsurlara da ihtiyaç duyulmaya başlanmıştır. Değişen pazarlarla birlikte tüketici ve tüketici davranışlarındaki değişiklikler de sürece eklenmiş ve hedef kitlelerce "senin farkın ne" sorusu sıkça sorulmaya başlamıştır. Değiş̧en tüketici yalnızca ürün ve hizmetlerde değil kuruluşlarda da değişiklik talep etmektedir.

Her kuruluş hedef kitleleriyle kurumsal iletişim faaliyeti yürütmekte ve onlarla kurduğu iletişimi olumlu bir ilişkiye dönüştürmeye gayret göstermektedir. Kitlelerle kurulacak olan olumlu ilişki; kuruluşun hedef kitlesi üzerinde olumlu imaj yaratmasını da sağlarken aynı zamanda kuruluşun amaçlarını, değerlerini, insan kaynakları politikalarını, hedeflerini, finansal performansını, çevre ve toplum için ne yaptığını anlatma firsatı da verecektir. Bu ilişki aynı zamanda şirketlere diğerleriyle aralarında olan farkı anlatma firsatı da verecektir.

Herhangi bir kişi veya grupla kurulan iletişimde ilk yapılan şey karşılıklı olarak kendini tanıtmaktır. İki yönlü iletişimde taraflar birbirlerini ne kadar çok tanırlarsa, iletişimleri daha güçlü olur ve aralarındaki güven daha da artmış olur. "Sen kimsin" sorusu iletişimin ilk basamağ niteliğindedir. Kılık kıyafetten isme, değerlerden mezun olunan okula kadar birbirinden farklı birçok unsur kişisel kimliği yansıtma adına ipuçları vermektedir. Hatta bazen kim olduğunu tanıtmak için kartvizit kullanıldığı gibi, bazen de kimlik göstermek gerekebilmektedir.

Kuruluşlar da kendilerini tanıtırken görsel, yazılı, psikolojik ve davranışsal anlamda birçok unsuruyla kimliklerini ortaya koymaktadırlar. Yansitılan bu kimlik, hedef kitleler tarafından algılanmakta ve kuruluşa dönük imaja önemli oranda etki etmektedir.

Dijital dönüşümle birlikte kurumsal kimlik unsurları kurumsal web sitelerine taşınmış ve kurumlara çok büyük avantajlar sağlamıştır. Kurumsal kimlik kurumsal imaj üzerinde önemli ölçüde etkiler yarattığından dolayı, imaj yönetimi ve takibi özen gösterilmesi gereken bir unsur haline gelmiştir. Şirketlerin kurumsal kimliklerini kurumsal web sitelerinde nasıl yansittıkları ve yeterli olarak yansitıp yansitamadikları sık sık ölçülmesi gereken bir konu durumundadır. Bu konuda oluşacak bir hata ya da eksiklik kurumun olumsuz bir imajla tanınmasına ve devamında düşük bir itibara neden olabilecektir.

\section{Kurumsal Web Siteleri}

İnternetin meydana getirdiği gelişmelerle birlikte kurumsal kimliğe ait unsurlar kurumsal web sitelerine taşınmıştır. Önceleri yalnızca tek taraflı iletişime açık olan kurumsal web siteleri, web 2.0'la birlikte müşteriyle iki yönlü iletişime de imkân verir hale gelmişlerdir.

Kurumsal web siteleri şirketlere kurumsal kimliklerini sunmak için yer ve firsat sunmaktadırlar (Mohammed vd., 2016: 676). Şirketler müşterilerine kolay erişim sağlama ve maliyet düşürme avantajı sağladığından beri birçok karmaşık bilgiyi web 
siteleri yoluyla farklı hedef kitlelerine sunmaktadır (Morhard, 2010: 437). Kurumsal web siteleri şirketlerin kurumsal faaliyetleri konusunda paydaşlarını bilgilendirmesi, onlarla ilişki kurması ve meşruiyet kazanması için en etkili yollardan birisidir (Georgiadou ve Nickerson, 2020: 413). Web siteleri şirketlerin performansı hakkında bilgi verirken aynı zamanda olumlu bir kurumsal imajı şekillendirmek için de kullanılmaktadır (Park vd., 2013: 706). Bunlara ilave olarak şirketler web siteleri üzerinden sipariş almakta, satış yapmakta, hizmet vermekte, marka bilinirliğini artırmakta ve daha geniş şekilde kim olduklarını ve muhtemelen olmayı istedikleri yeri göstermektedirler (Pant ve Pant, 2018: 121).

Web sitelerinin içeriği şirketin amaç ve beklentilerine göre değişmektedir. Bir şirket ya da faaliyetin tanıtımı için yapılan bir kurumsal web sitesi elektronik broşür olma görevini görürken, hedef kitlesiyle iki yönlü iletişim kurmak isteyen şirketlerin web siteleri ise, daha ziyade geri bildirim sağlayacak şekilde düzenlenmektedir (Sayımer, 2012: 88).

\section{Kurumsal Kimlik}

“Medeniyetler Çatışması" kavramıyla 2000'li yılların başında çok ses getiren Samuel Huntington kültürler arası farklılıkların artık ideolojik ve politik değil kültürel olacağını belirtmiş, halk ve topluluklar için kimlik konusunun öne çıkacağını vurgulamıştır (2014: 24-25).

Kimlik kavramı TDK Türkçe Sözlükte insanı tanımlayan nitelik ve özellikler toplamı olarak tanımlanmıştır (TDK, 2020). Kimlik insanların ve kurumların hedef kitlelerini etkileyen, onlara ne olduklarını açıklayan ve tanıtan bir unsurdur. Değişen teknoloji ve sosyal yapıyla birlikte kurum kimliği kavramı da değişmiş ve kapsamı genişlemiştir. Kurumsal kimlik yıllarca görsel tasarım şeklinde algılanmış (Baskan Karsak, 2008: 168) ancak 1970'lerden itibaren özellikle şirketlerin farklılaşmasını sağlayacak kurumsal felsefe, kurumsal tasarım, kurumsal iletişim ve kurumsal davranış olarak daha geniş bir yelpazede incelenmeye başlanmıştır (Okay ve Okay, 2015: 571). Daha farklı bir deyişle bir şirketin kimliği, bir kuruluşun ona farklılık kazandıran unsurların karışımını ifade etmektedir (Balmer, 1998: 977). Farklılık sağlayan unsurlar önceleri iletişim şekli ve reklamlarla sinırliyken, giderek artan rekabet, sponsorluk ve sosyal sorumluluk faaliyetlerini de bu unsurlar arasına sokmuştur.

Kurumsal kimlik yukarıdaki bilgilere ilave olarak örgütün karakteri ve değerler sistemidir. Kurumsal kimlik denilen şey işletmelerin kendileri hakkındaki fikirleridir (Brotzen 1999: 53). Kurumsal kimlik üzerinde en önemli etkiye sahip olan grup, iç paydaşlar olan örgüt çalışanlarıdır. Çalışanlar, örgütün dışa yansıyan yüzü konumundadır ve müşterilerle doğrudan temas halindedir. $\mathrm{Bu}$ nedenle, örgüt çalışanlarının tutum ve davranışlarının kurumsal kimlik üzerinde önemli ölçüde etkili olduğu söylenebilir. Örgütler, hedeflerine ilerleme esnasında, çalışanlarının ihtiyaçlarını da hesaba katmaları gerekmektedir. İhtiyaçları karşılanan çalışanların hem performansı hem aidiyetleri hem de motivasyonları artacaktır (Karaköse, 2007: 16). Motive olan ve aidiyeti artan çalışanların 
biz duygusu artacak ve kurumsal kimliğin kurumsal davranış boyutuna katkı sağlanmış olacaktır (Okay ve Okay, 2015: 572).

Kurumsal kimlik asıl olarak görsel göstergelerle somutlaşmaktadır. Büroların, üretim tesislerinin yer aldığı binalar ya da alanlar, reklamlar, kurumun logosu, sloganları, renkleri, ismi, kurumsal davranışı ve kurumsal iletişimi kurumsal kimliğin dişa yansıyan unsurlarıdır (Balta Peltekoğlu, 2016: 538-541).

Kurumsal kimlik, kuruluşun yapısına göre de farklılık gösterebilmektedir. Olins (2002:3) kurumsal kimliği üçe ayırmaktadır. Bunlar tekli kimlik, marka kimliği ve desteklenmiş kimliktir. Tekli kimlik yapısında şirket tüm etkileşimleri boyunca aynı isim ve görsel sistemi kullanmaktadır. Organizasyonun yaptığ 1 her şey aynı isim, stil ve karaktere sahip olduğu için her bölüm diğerini desteklenmektedir. Marka kimliği yapısında ise bazı şirketler özellikle tüketiciye dönük birden fazla markaya sahip olanlar, kurumsal kimliklerini sahip oldukları marka kimliklerinden ayırmaktadırlar. Nihai tüketici marka ile özdeşleşirken diğerleri kurumsal kimlikle özdeşleşmektedir. Böylece markalar kendilerine ait isim, itibar ve yaşam döngüleri ile hem aynı şirketteki markalarla hem de sektördeki diğer markalarla rekabet edebilme olanağı kazanmaktadır (Olins, 2002: 3). Desteklenmiş kimlikte farklı alanlarda çalışan şirketler kendi yönetim biçimlerini ve davranışlarını devam ettirirken, bağlı oldukları üst kimlikle olan bağ bir şekilde vurgulanır. Koç grubuna ait Arçelik-Aygaz gibi şirketlerin reklam ve ürünlerinde üst kuruluşu belirtmeleri veya Toyotasa ve Brisa gibi şirketlerde üst şirket Sabancı isminin markaya bir şekilde iliştirilmiş olması örnek gösterilebilir (Okay, 2013: 34-35).

Okay (2013: 44) kurumsal kimlik unsurlarını; kurumsal felsefe, kurumsal iletişim, kurumsal davranış ve kurumsal tasarım olarak sıralarken, Melawer ve Karaosmanoğlu (2006) kurumsal felsefe yerine kurumsal kültür kavramını kullanmış ve yukarıdaki listeye kurumsal yapı, endüstriyel kimlik ve kurumsal stratejiyi de eklemiştir. Yazarlar kurumsal kültürün strateji, yapı ve davranışı etkilediğini belirtmektedir. Diğer taraftan kurumsal strateji, kurumsal kültür, kurumsal davranış ve kurumsal görünüm ise kurumsal iletişimi etkilemekte, bu etkileşimler sonunda kurumsal kimlik ortaya çıkmaktadır (Melawer ve Karaosmanoğlu, 2006: 865). Genel literatür incelendiğinde yazarların kurumsal kimlik unsurları olarak kurumsal tasarım, kurumsal davranış, kurumsal kültür, kurumsal iletişim ve kurumsal yapı unsurlarını kullandığ1 görülmektedir (Balmer, 1998; Balta Peltekoğlu, 2016; Baskan Karsak, 2008; Doğan, 2017; Gray \& Balmer, 1998; Mert, 2018).

Yukarıdaki açıklamalar dikkate alındığında kurumsal kimliğin beş unsuru aşağıdaki gibidir.

Kurumsal Kültürr; çalışanlara yol gösteren kurallar ile kurumların olayları ele alış biçimi (Balta Peltekoğlu, 2016: 542) ve işletmelerin kendileri hakkındaki temel düşünceleridir (Okay ve Okay, 2015: 574). Kurumsal kültürün ilk unsuru şirketin binası ve dış müşteriye karşı davranışından oluşan fiziksel görüntüsüdür. İkinci unsur işgörenlerin işlerine dönük tutumları ve etik kurallardır. Üçüncü unsur ise işgörenlerin kurumsal kültüre olan bağlılıkları ve bunu işlerinde göstermeleridir (Balta Peltekoğlu, 2016: 542).

Kurumsal Davranış; bir kurumun belli bir duruma karşı kendine has davranış 
ve eylemleridir. Kuruluşun herhangi bir durum karşısında göstermiş olduğu tepkilerin bütününü ifade etmektedir (Okay, 2013: 46). Bu davranış şirket kültürüne uygun olarak planlanmış ya da tesadüfen gerçekleşen kurumsal eylemlerin toplamıdır (Schmidt, 1995). Bu davranışlar gerek kurum çalışanlarına dönük davranışlar ve gerekse kurum dışındaki kişilere dönük davranışlar olarak sıralanabilir. Bu davranışları hedef kitleye dönük ekonomik, toplumsal, siyasi, hukuki, kalite ve insan kaynakları alanlarında yapılan bilgilendirmeler olarak sıralamak mümkündür.

Kurumsal Tasarım; bir kuruluşun görünür unsurlarla kendini anlatma çabalarıdır (Okay, 2013: 47). Bu ifade etme şekli firmanın bütün görünen unsurları ile tipografik stil, renk ve formlar gibi tüm karakteristik unsurlarının firmaya özgü bir tasarım sistemi olarak ortaya konmasıdır (Schmidt, 1995). Kurumsal tasarım şirket ismi, slogan, logo, renkler ve bina mimarisinden çalışanların giyimi ve antetli kağıtlara kadar tüm görünen kısımların stilini içermektedir.

Kurumsal İletişim; kurum kimliğinin iletişim araçlarıyla ifadesidir (Okay, 2013: 48). Bu durum, bir şirketin resmi ve gayri resmi kaynaklarından gelen kurum kimliğine dönük mesajların çeşitli medya aracılığıyla tüm hedef kitlelerine ve paydaşlarına iletilmesi şeklinde gerçekleşir (Gray ve Balmer, 1998: 699). Melawer (2003) kurumsal iletişim unsurlarını kontrollü kurumsal iletişim, yönetimsel iletişim, pazarlama iletişimi, örgütsel iletişim, kontrol edilemeyen iletişim ve doğrusal olmayan iletişim olarak siralamaktadır (214-215). Kurumsal iletişimin dişarıya yansıyan yüzü ise; sosyal sorumluluk kampanyaları, sponsorluk faaliyetleri, tanıtıcı reklamlar, kurumsal tanıtım filmleri, basın bültenleri, medya arşivleri ve duyurular gibi unsurlarla karşımıza çıkmaktadır. Kurumsal iletişim örgütlerin pazarlama faaliyetlerinde etkili olan tutundurma faaliyetleri ile araştırmalar ve çalışanlarla iletişim gibi araçlardan yararlanır (Okay ve Okay, 2015: 575).

Kurumsal Yapı; marka yapısı ve örgütsel yap1 olarak kendisini göstermektedir (Melewar, 2003: 216). Marka yapısı ürünlerin ve iş birimlerinin markalaşması ve hedef kitlesine nasıl göründüğü ile ilgilenir. Bu yapıda marka stratejisi de önemli bir yer tutmaktadır (Gray ve Semeltzer, 1985: 73). Örgütsel yapı ise, bir örgütün onu oluşturan birimleri arasındaki iletişim, kontrol ve otorite modellerini özetleyen yerleşik ilişki modelidir (Melawer ve Saunders, 1998: 292).

Kurumsal kimlik sektörde farklılaşma yaratabildiği oranda hedef kitlelerin gözünde olumlu imaja katkıda bulunabilir ve olumlu imajların birikimiyle de şirket itibarını artırabilir. Kurumsal kimliğin faydaları şu şekilde özetlenebilir (Melewar, 2003: 196197):

- Çalışan motivasyonunu artırır.

- Kurumsal amaç ve misyon konusunda çalışanları bilgilendirir.

- Çalışanların mevcut kurum kültürüne uyum göstermelerini kolaylaştırır. Özellikle, muhtemel birleşme ve satın alma sonucu oluşacak kültürel değişimlerde bütünleşme sağlanması kolaylaşır.

- Yüksek nitelikli çalışanları kurma çeker. 
- Hissedarlar ve yatırımcılar örgütü daha iyi tanıma firsatı elde ederler.

- Hissedar ve ortakların kuruma dönük farkındalıkları artar.

- Tüketiciler kurumun ürün ve kalitesi hakkında fikir sahibi olur.

- Marka tanınırlığını artırır.

Kurumsal kimlikler hiçbir zaman sabit değildir ve sürekli bir değişim halindedir. İçsel ve dişsal değişim, kurumsal kimlik ve pazarlama faaliyetlerinin değişimi açısından bir domino etkisi yaratacaktır. Kurumsal kimliği yönetirken üst düzey yöneticilerin aşağıdaki soruları öncelikle dikkate almalarında fayda vardır (Balmer, 2017: 1474-1475):

- Kuruluşun amacı nedir?

- Şirket ne tür bir iş yapmaktadır?

- Kuruluşun ayırt edici ve farklılaştırıcı özellikleri nelerdir?

- Kuruluşun yasal olarak ne yapmasına izin verilmiştir?

- Kuruluş yasal olarak kimin için ve kimin yararına faaliyet göstermektedir?

- Kuruluş müşterilere ve yatırımcılara ne gibi bir değer katmaktadır?

- Kuruluşun müşteri ve yatırımcılarla arasındaki karşılıklı kârlılık ilişkisinin niteliği nedir?

- Kuruluşun müşteriler, çalışanlar, yatırımcılar ve diğer kilit paydaş gruplar arasındaki imaj ve itibarı ne seviyededir?

- Kuruluş kurumsal iletişim konusunda hangi mesajları kime iletecektir?

- Kuruluşun rekabet ve iş ortamında daha dikkatli olması için ne gibi değişikler yapılabilir?

Kurumsal kimliğin web sayfaları ile sunulması konusunda yapılmış araştırmalar aşağıya çıkartılmıştır.

\section{İlgili Araştırmalar}

\begin{tabular}{|c|c|c|}
\hline Yazar & Konusu & Bulgular \\
\hline $\begin{array}{l}\text { Banu Başkan } \\
\text { Karsak, (2008). }\end{array}$ & $\begin{array}{l}\text { "Web Sitelerinin } \\
\text { Kurumsal Kimlik } \\
\text { Açısından } \\
\text { Değerlendirilmesi: En } \\
\text { Beğenilen } 20 \text { Şirket } \\
\text { Üzerine Bir Analiz" }\end{array}$ & $\begin{array}{l}\text { Çalışmada şirketlerin web sayfaları kurumsal kimliğin dört boyutu } \\
\text { çerçevesinde analiz edilmiştir. Web sayfalarında logo, renk, yazı } \\
\text { stili gibi görsel kimlik ögeleri etkin olarak yansıtılırken markanın } \\
\text { insani özelliği olan marka karakteri ise aynı oranda yansıtılmamıştır. } \\
\text { Şirketler ikinci kimlik boyutu olan dış hedef kitle ile kurumsal } \\
\text { iletişim araçlarını etkin olarak kullanmışlardır. Projeler ve sosyal } \\
\text { sorumluluk kampanyaları gibi. Ancak kurum içi iletişim araçları } \\
\text { (intranet) oldukça düşük seviyededir. Kurum felsefesi unsurları } \\
\text { olan değerler, kuruluş bilgisi ögeleri tüm şirketlerin sayfalarında yer } \\
\text { almaktadır. Ancak vizyon, misyon ve amaçlar hakkında bilgi veren } \\
\text { şirket sayısı ise azdır. Kuruluşlar kurumsal davranış boyutu olarak } \\
\text { ekonomik bilgilendirme ve ürün hizmet bilgilendirmeleri, çalışanlara } \\
\text { dönük bilgilendirmeleri etkin olarak yapmalarına rağmen, siyasi ve } \\
\text { hukuki bilgilendirmeleri ise yapmamışlardır. }\end{array}$ \\
\hline
\end{tabular}




\begin{tabular}{|c|c|c|}
\hline $\begin{array}{l}\text { Duygu Doğan, } \\
\text { (2017)). }\end{array}$ & $\begin{array}{l}\text { "Fortune } 500 \\
\text { Siralamasındaki Türk } \\
\text { Havayolu Şirketlerine } \\
\text { Ait Kurumsal Web } \\
\text { Sitelerinin Kurum } \\
\text { Kimliği Açısından } \\
\text { Değerlendirilmesi" }\end{array}$ & $\begin{array}{l}\text { Çalışmada beş havayolu şirketinin web sayfaları kurumsal kimliğin } \\
\text { beş boyutu çerçevesinde analiz edilmiştir. Kurumsal kültür ve } \\
\text { kurumsal davranış diğer boyutlara göre daha yüksek oranda web } \\
\text { sayfalarında yer bulmuştur. En zayıf boyut ise kurumsal tasarım } \\
\text { olarak görülmüştür. Şirketlerin kurumsal iletişim araçlarını etkin } \\
\text { olarak kullandıkları görülmüştür. Bu boyutta sponsorluk faaliyetleri } \\
\text { öne çıkmıştır. Sosyal sorumluluk faaliyetleri ise kısıtll sayıda kendine } \\
\text { yer bulabilmiştir. Vizyon, misyon ve kurumsal değerler ifadelerde } \\
\text { eksiklerde olsa yeteri kadar vurgulanmıștır. }\end{array}$ \\
\hline $\begin{array}{l}\text { Sevim } \\
(2017)\end{array}$ & $\begin{array}{l}\text { "Kurumsal Web } \\
\text { Sitelerinin Kurum } \\
\text { Kimliği Açısından } \\
\text { İncelenmesi: En } \\
\text { Çok Tercih Edilen } \\
\text { Üniversiteler Üzerine } \\
\text { Bir Analiz" }\end{array}$ & $\begin{array}{l}\text { Çalışmada öğrenci tercihlerinde ilk } 10 \text { 'da yer alan üniversitelerin } \\
\text { kurumsal web sayfaları kurumsal kimliğin yedi boyutu çerçevesinde } \\
\text { analiz edilmiştir. İncelenen tüm üniversitelerin web sayfaları kurumsal } \\
\text { tasarım ilkelerine uygun olarak hazırlanmıştır. Ancak grafik, ses } \\
\text { ve hareketli görüntüler daha az kullanılmıştır. Kurumsal kimlik } \\
\text { boyutunda üniversiteler yeterli seviyededir ancak medya araçlarının } \\
\text { medya başlı̆ı altında saklanması tavsiye edilmektedir. Çalışmada } \\
\text { kurum kültürü boyutu yeterli bulunmamıştır. Etik kurallar, amaçlar ve } \\
\text { politika duyurumunda yetersizlik görülmüştür. Yine web sitelerinde } \\
\text { kurucular yeterli oranda yer almamıştır. Törenlere bu boyutta yeteri } \\
\text { kadar yer verilmiştir. Kurumsal davranış web sayfalarında çoğunlukla } \\
\text { bilgilendirme amaçlı kullanılmı̧ı̧tır. Ancak üniversitelerin yurt dış1 } \\
\text { tanınırlığı açısından yeteri kadar çaba göstermedikleri görülmüşsür. } \\
\text { Kurumsal yapida üst yönetim gösterilirken örgüt şeması ise yer } \\
\text { almamıştır. Üniversitelerde YÖK kuralları gereği endüstri kimliği } \\
\text { yerleşmiş durumdadır. Üniversiteler stratejik boyut olarak yeni bölüm } \\
\text { açma, sanayi ile iş birliği yapma, yurtdışındaki üniversitelerle iş birliği } \\
\text { yapma gibi çalışmalara gitmektedirler. }\end{array}$ \\
\hline $\begin{array}{l}\text { İbrahim } \\
\text { Mohammed vd. } \\
\text { (2016). }\end{array}$ & $\begin{array}{l}\text { "An Empirical } \\
\text { Investigation of } \\
\text { Corporate Identity } \\
\text { Communication on } \\
\text { Hong Kong Hotels' } \\
\text { Websites" }\end{array}$ & $\begin{array}{l}\text { Bu çalışmada Hong Kong'da bulunan } 123 \text { otelin web sayfaları } \\
\text { kurumsal kimliğin altı boyutu (kurumsal tasarım, kurumsal iletişim, } \\
\text { kurumsal yapı, strateji, kültür ve davranış) çerçevesinde analiz } \\
\text { edilmiştir. Kurumsal tasarım boyutunda bütün oteller logo ve isim } \\
\text { konularında yeterli seviyede görülmüştür. Ancak, slogan konusunda } \\
\text { çok düşük seviyede kalmışlardır. Kurumsal yapı, kurumsal davranış } \\
\text { ve kurumsal strateji aynı şekilde çok düşük seviyelerde kalmıştır. } \\
\text { Kurumsal kültür ise otellerin yaklaşık yarısının web sayfalarında } \\
\text { kendilerine yer bulmaktadır. }\end{array}$ \\
\hline Rafael & $\begin{array}{l}\text { "Projecting Banks } \\
\text { Identities Through } \\
\text { Corporate Websites: } \\
\text { Comparative Analysis } \\
\text { of Spain and United } \\
\text { Kingdom" }\end{array}$ & $\begin{array}{l}\text { Çalışmada Ingiltere'den ve Ispanya'dan } 30 \text { 'ardan toplam } 60 \text { banka } \\
\text { üzerinde kurumsal kimlik boyutları üzerinden analiz yapılmıştır. } \\
\text { Çalışma sonuçlarına göre, İspanya ve İngiltere bankalarının } \\
\text { kurumsal web siteleri arasında marka kimliğini yansıtma anlamında } \\
\text { farklılık görülmüştür. Genel olarak İngiltere'de bulunan bankalar } \\
\text { marka kimliklerini yansıtmak için sosyal ve stratejik yönleri ön plana } \\
\text { çkartırken İspanya'daki bankalar iletişimle ilgili bilgileri ön plana } \\
\text { çkartmaya çalışmaktadır. }\end{array}$ \\
\hline
\end{tabular}

\section{Yöntem}

$\mathrm{Bu}$ çalışmanın amacı, Konya'daki şirketlerin kurumsal kimlik uygulamalarının web siteleri üzerinden nasıl gerçekleştirildiğini analiz etmektir. Çalışmanın evreni Konya'daki şirketler olup örneklemi ise İstanbul Sanayi Odası (2019) verilerine göre 
2019 yılında Türkiye'de en büyük ilk ve ikinci 500 şirket arasında yer alan Konya'daki 22 şirkettir. Çalışma 1-30 Kasım 2020 tarihleri arasında söz konusu şirketlerin kurumsal web siteleri üzerinden gerçekleştirilmiştir. Konya'da 2019 verilerine göre 15 bin 909 faal işyeri (KTO, 2019: 59) bulunmasına karşılık yalnızca İSO'nun listesine giren 22 şirketin ele alınması çalışmanın sınırlılığını oluşturmaktadır. Çalışmada ilgili şirketlerin sosyal medya hesapları üzerinde kurumsal kimlik çalışması yapılmaması da çalışmanın bir başka sınırlılığını oluşturmaktadır. Araştırmada aşağıdaki sorulara cevap aranacaktır:

- Şirketler, kurumsal tasarım unsurlarını web sitelerine yansıtabilmişler midir?

- Şirketler, kurumsal iletişim unsurlarını web sitelerine yansıtabilmişler midir?

- Şirketler, kurumsal kültür unsurlarını web sitelerine yansıtabilmişler midir?

- Şirketler, kurumsal davranış unsurlarını web sitelerine yansıtabilmişıler midir?

- Şirketler, kurumsal yapı unsurlarını web sitelerine yansıtabilmişler midir?

Çalışmada söz konusu şirketlerin web siteleri, kurumsal kimlik unsurlarına göre oluşturulan kodlama formu yardımıyla taranmış ve içerik analizi tekniğiyle analiz edilmiştir. Kodlama formunun oluşturulmasında Mert'in (2018) ve Baskan Karsak'ın (2008) çalışmalarından yararlanılmış, hazırlanan kodlama formu uzman personel ve öğretim elemanlarının görüşleriyle son halini almıştır. Bu kapsamda şirketlerin web siteleri 1-30 Kasım 2020 tarihleri arasında incelemeye alınmış ve kodlama formuna kodlama yapılmıştır. Kodlamalarda kurumsal kimlik unsurlarının web sitelerinde bulunup bulunmadığına göre kayıt tutulmuştur. Veriler yalnızca araştırmacı tarafından kodlanmıştır.

\section{Bulgular ve Tartışma}

Araştırma kapsamında İSO tarafından 2019 yılında Türkiye'nin ilk ve ikinci 500 listesinde yer alan Konya şirketlerinin kurumsal web siteleri incelenmiştir. Araştırma kapsamında 22 şirket bulunmaktadır. Bu şirketler sırasıyla şunlardır; Konya Şeker, Eti Alüminyum, Panagro Tarım, AYD Otomotiv, Ova Un, Safa Tarım, Enka Süt, Hekimoğlu Un, RTM Tarım, Kombassan Kâğıt, Akova Süt, Atıker Makine, Tümosan Motor, Büyükhekimoğulları Un, İzi Süt, Altınapa Değirmencilik, Çöğenler Yem, Yıldız Pul, Konya Çimento, Sezersan Matbaacılık, Helvacızade Gıda ve Kompen PVC'dir. İçerik analizi yöntemiyle incelenen web sayfalarına ait bulgular aşağıya çıkartılmıştır.

Çalışmada analizi yapılan 22 şirketin tamamının kurumsal web sitesi mevcuttur. Çalışmanın başında Akova Süt ve Gıda Mamülleri A.Ş.'nin kurumsal web sitesi yok iken, çalışmanın sonunda yapılan kontrolde ise resim, logo, tasarım vb. görsel tasarım içermeyen ve birkaç saat içinde tasarlanabilecek yedi sayfalık düz yazıdan oluşan bir web sitesi yapıldığı görülmüştür. Analizi yapılan şirketlere ait faaliyet alanları Tablo 1'de sunulmuştur. 
Tablo 1. Şirketlerin Faaliyet Alanları

\begin{tabular}{lcc}
\hline \multicolumn{1}{c}{ Faaliyet Alanı } & Sayı & Yüzde \\
\hline Gida & 12 & $\% 55,5$ \\
Otomotiv & 4 & $\% 18,2$ \\
Basım & 2 & $\% 9,1$ \\
Ana Metal & 1 & $\% 4,5$ \\
Kimya & 1 & $\% 4,5$ \\
Çimento & 1 & $\% 4,5$ \\
Plastik & 1 & $\% 4,5$ \\
Toplam & 22 & $\% 100,00$ \\
\hline
\end{tabular}

Tablo 1'e göre şirketlerin \%55,5'i gida, \%18,2'si otomotiv, \%9,1'i basım, \%4,5'i ana metal, \%4,5'i kimya, \%4,5'i çimento ve \%4,5'i plastik sanayinde yer almaktadır. 2019 verilerine göre Konya tarımsal alan büyüklüğünde Türkiye'de birinci sırada gelmektedir. Konya yine süt üretimi ve şekerpancarı üretiminde Türkiye' de birinci durumdadır (KTO, 2019, s. 37-47). Bu sonuçlara bakıldığında İSO ilk ve ikinci 500 listesinde yer alan araştırmadaki şirketlerin yarıdan fazlasının gıda şirketi olması beklenen bir durum olarak görülmektedir. Şirketlerin kurumsal kimlik unsurlarının web sitelerindeki dağılımı ise Tablo 2'de sunulmuştur.

Tablo 2. Web Sitelerindeki Kurumsal Kimlik Unsurlarının Ait Dağılım

\begin{tabular}{lcc}
\hline \multicolumn{1}{c}{ Unsur } & Ortalama & Yüzde \\
\hline Kurumsal kültür & 11,4 & 51,8 \\
Kurumsal tasarım & 10,6 & 48,4 \\
Kurumsal iletişim & 10,06 & 45,7 \\
Kurumsal davranış & 9,4 & 42,7 \\
Kurumsal yapı & 9 & 40,9 \\
\hline
\end{tabular}

Tablo 2'de şirketlerin web sitelerinde kurumsal kültürün beş unsurunun dağılımı görülmektedir. Buna göre; kurumsal kimlik unsurlarından kurumsal kültür \%51,8 ile ilk sırada yer alırken, onu sırasıyla \%48,4 ile kurumsal tasarım, \%45,7 ile kurumsal iletişim, $\% 42,7$ ile kurumsal davranış ve \%40,9 ile kurumsal yapı takip etmektedir. Şirketler kültür, tasarım ve iletişim unsurlarında yarıya yakın bir performans sergilerken, davranış ve yap1 unsurlarında ise ancak yüzde 40'ları bulabilmektedir. Bu durum Doğan'ın (2017) Türkiye'de faaliyet gösteren beş havayolu şirketi üzerinde yaptığı çalışmasıyla kısmen örtüşmektedir. Doğan'ın çalışmasında da kurumsal kültür ve kurumsal iletişim ilk üç içinde çıkan unsurlar olmuşlardır. Doğan'ın çalışmasında unsurların oranı \%41-65 arasında değişmektedir. Yine Baskan Karsak'ın (2008) en beğenilen 20 şirket üzerinde yapmış olduğu çalışmada da kurumsal felsefe (bu çalışmada kurumsal kültür) ilk sırada çıkan kurumsal kimlik unsuru olmuştur. Çalışmada unsurların oranı \%65-80 arasında 
değişmektedir. Bu sonuçlar Konya'da yer alan şirketlerin kurumsal kimlik unsurlarının web sayfalarına taşınması konusunda henüz gerekli dijital dönüşümü sağlayamadıklarını göstermektedir. Yine yukarıda ortaya konan üç farklı çalışma, daha itibarlı/en beğenilen şirketlerin kurumsal kimliklerini kurumsal web sayfalarına taşımada daha fazla çaba sarf ettiklerini göstermektedir.

Tablo 3. Web Sitelerindeki Kurumsal Tasarım Unsurlarına Ait Dağılım

\begin{tabular}{lcc}
\hline \multicolumn{1}{c}{ Göstergeler } & Var (Sayı) & Var (Yüzde) \\
\hline Logo & 21 & $\% 95,5$ \\
Logoya ait bilgiler & 0 & $\% 0,0$ \\
Kurum rengi & 16 & $\% 72,7$ \\
Marka karakteri & 9 & $\% 40,9$ \\
Slogan & 5 & $\% 22,7$ \\
Mimari tasarım & 13 & $\% 59,1$ \\
Kurumsal tasarım ortalaması & 10,6 & $\% 48,4$ \\
\hline
\end{tabular}

Tablo 3'te kurumsal tasarım unsurlarına ait dağılım yer almaktadır. Kurumsal tasarım unsurlarından biri olan logolar şirketlerin karakterini yansıtan ve şirketlerin görsel farklılığını ortaya koyan unsurlardır. Şirketler logolarına gerekli özeni gösterirler ve şirketlerinin karakterini yansıtan bir logo oluşturmaya çalışırlar. Tabloya göre kurumsal web sitelerinin \%95,5'inde şirket logosu bulunmaktadır. Akova Süt şirketinin web sitesinde ise logo dahil kurumsal tasarım unsurlarına ait hiçbir unsur bulunmamaktadır. Şirketlerin logoları görsel iletişimi en iyi şekilde sağlamak amacıyla web sayfasının sol üst kösesine yerleştirilmiştir. Logolar şirket karakterlerini yansıttıklarından, şirkete ait ürünlerde ve basılı materyalde kullanılacak şirket logosunun renk, şekil ve boyutlarına ait bilgiler bir katalog halinde web sayfasında bulunması gerekmektedir. Yukarıdaki tabloya göre logolar web sitelerinin tamamına yakınında bulunmasına rağmen logoya ait bilgiler ise hiçbir web sitesinde bulunamamıştır. Bu durum logoyla ilgili tasarımlarda bir standart oluşturulmadığından karmaşaya sebep olabilecektir. Renkler de logolar gibi şirket kimliklerini yansitan ögelerden bir tanesidir. Şirketlerin \%72,7'si web sitelerinde, reklamlarında ve fiziki unsurlarında kendilerine özgü renkleri tercih etmişlerdir. Şirketlerin çoğunluğu görsel algılamayı kolaylaştırmak için fon rengini açık, metin rengini ise koyu renklerden tercih etmiştir. Yine şirketler kurum kimliklerine dönük bir rengi web sayfalarına taşımışlardır. Konya Şeker, Enka Süt ve Ova Un gibi gıda şirketleri doğal yeşil renklere sayfalarında daha çok yer vermiş, bir ana metal şirketi olan Atıker Makine kırmızı beyaz renkleri ve otomotiv yedek parçası üreten AYD Otomotiv ise koyu mavi renkleri tercih etmiştir. Marka karakteri markayla özdeşleşen insani özellikler olarak adlandırılabilir. Marka karakteri kullanımı şirketlerce yeteri kadar benimsenmemiş yarıdan daha azı, \%40,9'u marka karakterini sayfalarına yansıtmıştır. Enka Süt, Hekimoğlu Un, RTM Tarım, Atıker Makine, Tümosan Motor, Büyükhekimoğlu Un, Ova Un, Altınapa Un, Çöğenler Yem ve Helvacızade Gida şirketleri marka karakteri unsurlarına web sitelerinde yer vermişler ve görsel kimliklerini güçlendirmişlerdir. Marka sloganları marka bilinirliğini 
artırırken aynı zamanda marka imajına da olumlu katkı sağlar. Tabloya göre şirketlerin ancak \%22,7'si kurumsal web sayfalarında slogan kullanmışlardır. Bu durum markaların marka imajı ve bilinirlik açısından kendilerine katkı sağlayacak olan slogan konusuna yeteri kadar dikkat etmediklerini göstermektedir. Web sitelerindeki mimari tasarım gerek kullanıma uygunluk ve gerekse ilgiyi çekebilecek yenilikçi ve yaratıcı unsurlar içermesi durumudur. Web sitelerinin \%59,1'i web sitelerinden bulunmas1 gereken temel mimari unsurlara yer vermiştir. Bu sonuçlar Baskan Karsak'ın (2008) Türkiye'deki en beğenilen 20 şirket ve Muhammed vd.nin (2016) Hong Kong'daki 123 otel üzerinde yaptıkları çalışma sonuçlarıyla örtüşmektedir. Şirketler çoğunlukla logo ve kurum renklerini web sayfalarına taşımış olmalarına rağmen marka karakterlerini ve sloganlarını ise web sayfalarına taşıyamamışlardır.

Tablo 4. Web Sitelerindeki Kurumsal İletişim Unsurlarına Ait Dağılım

\begin{tabular}{lcc}
\hline \multicolumn{1}{c}{ Göstergeler } & Var (Sayı) & Var (Yüzde) \\
\hline Yabancı dilde site & 12 & $\% 54,5$ \\
Kurum içi iletişim-intranet & 6 & $\% 27,3$ \\
Sosyal sorumluluk kampanyası & 4 & $\% 18,2$ \\
Sponsorluk & 1 & $\% 4,5$ \\
Pazarlama ve satış odaklı içerik & 21 & $\% 95,5$ \\
Tanıtıcı reklamlar & 9 & $\% 40,9$ \\
Kurumsal tanıtım filmi & 10 & $\% 45,5$ \\
Basın bültenleri & 6 & $\% 27,3$ \\
Medya arşivi & 6 & $\% 27,3$ \\
Kuruluş yayınları & 7 & $\% 31,8$ \\
Duyurular & 3 & $\% 13,6$ \\
Haberler/etkinlikler & 6 & $\% 27,3$ \\
E-Posta & 20 & $\% 90,9$ \\
Kurum iletişim bilgileri & 20 & $\% 90,9$ \\
Sosyal medya hesabı & 13 & $\% 59,1$ \\
Online iletişim formu & 17 & $\% 77,3$ \\
Kurumsal iletişim ortalaması & 10,06 & $\% 45,7$ \\
\hline
\end{tabular}

Web sitelerinde yer alan kurumsal iletişim unsurlarına ait veriler Tablo 4'te belirtilmiştir. Şirketlerin \%54,5'i web sitelerinde İngilizce dil seçeneği bulundurmakta, Yıldız Pul sekiz, AYD Otomotiv beş, Kombassan Kâğıt dört, Konya Şeker ise iki dilde daha hizmet vermektedir. Şirketlerin \%27,3'ünde kurum içi iletişime imkân veren intranet bulunmakta ve bu hizmeti çoğunlukla ödeme ve bayi iletişimi için kullanmaktadırlar. Konya Şeker ise "Çiftçi Portalı" adlı daha kapsamlı bir intranet hizmeti sunmaktadır. Konya Şeker'in bu hizmeti ile; çiftçilere duyuru ve haberler verilmekte, eğitimler yapılmakta, ürün fiyatları öğrenilmekte, alınan avans ve primler görülebilmekte, ekilen tarlanın toprak yapısı ve bitki gelişim durumu görülebilmektedir. Şirketleri toplum nezdinde birer vatandaş 
kuruluş haline getiren sosyal sorumluluk faaliyetleri şirketlerin yalnızca \%18,2'sinde ve sponsorluk ise \% 4,5 'inde bulunmaktadır. Sosyal sorumluluk faaliyetlerinde Konya Şeker ilk sırada gelmektedir. Konya Şeker, halen 19 milyon ağaç dikmiş ve Türkiye nüfusu kadar ağaç dikmeyi hedeflemiştir. Bununla birlikte Konya Şeker Ortaokulu binasının yapımı, Kızılay'a kan bağışı kampanyası ile Ana Kız Okuldayız projesine katkıları Konya Şeker'in sosyal sorumluluk faaliyetlerinin örnekleri arasındadır. Eti Alüminyum ise, Seydişehir bölgesine 130 bin ağaç dikerek daha yaşanabilir bir çevrenin meydana gelmesine katkı sağlamıştır. Konya Çimento Güzel Sanatlar Lisesi'ni hem yaptırıp hem de tefriş etmiştir. Konya Çimento fabrika arazisi ve Takkeli Dağ bölgesine de toplam 88 bin ağaç dikmiştir. Şirketlerin web sayfalarının \%95'inde pazarlama ve satış odaklı içerik bulunmaktadır. Genel olarak bakıldığında şirketlerin web sayfalarını öncelikle pazarlama amaçlı olarak kullandıkları görülmektedir. Yine ürünlere yönelik tanıtıcı reklamlar web sitelerinin \%40,9'unda yer almıştır. Kurumsal tanıtım filmleri ise web sitelerinin $\% 45,5$ 'inde yer almaktadır. Analiz yapılan şirketlerden üç şirketin kurumsal tanıtım filmleri ise web sitelerinde değil Youtube üzerinde bulunmuştur. $\mathrm{Bu}$ şirketler kurumsal tanıtım filmini yaptırmış ancak web sayfalarına koyma gereğini duymamışlardır. Yine başka bir bulgu olarak şirketler medya ile ilişkilerini sağlayacak unsurları etkin olarak kullanamamışlardır. Medya kuruluşlarıyla iletişimde yararlanılan basın bültenleri \%27,3, medya arşivi \%27,3 ve duyurular \%13,6 oranında web sayfalarında yer alabilmiştir. Medya arşivi bulunan şirketler Konya Şeker, Eti Alüminyum, Panagro Tarım, AYD Otomotiv, Enka Süt ve Yıldız Pul şirketleridir Hedef kitlelerle iletişim amaçlı kullanılan online iletişim formu ise \%77,3 ile iyi seviyede görülmüştür. Kurumsal sosyal medya hesabı oranı $\% 59,1$ 'dir. $\mathrm{Bu}$ hesaplar çoğunlukla pazarlama amaçlı ürün tanıtımına dönük kullanılmış ve az sayıda önemli gün ve haftalara dönük mesajlar paylaşılmıştır. Baskan Karsak'ın (2008) çalışmasında en beğenilen şirketlerin tamamına yakını sosyal sorumluluk, sponsorluk, medya ile ilişkilere dönük paylaşımlara ve kampanyalarına yer verirken, incelenen şirketlerin birkaçı dışında bu faaliyetlere az sayıda yer vermeleri, konunun önemini ve hedef kitleler üzerindeki etkisini yeteri kadar kavrayamadıklarını düşündürmektedir. Yine bu durum şirketlerin kurumsal imajın oluşmasında basının çarpan etkisi yarattığı gerçeğini dikkate almadıklarını bir kez daha göstermektedir.

Tablo 5. Web Sitelerindeki Kurumsal Kültür Unsurlarına Ait Dağılım

\begin{tabular}{lcc}
\hline \multicolumn{1}{c}{ Göstergeler } & Var (Sayı) & Var (Yüzde) \\
\hline Kuruluş hakkında bilgi & 22 & $\% 100$ \\
Temel değerler/politikalar & 14 & $\% 63,6$ \\
Etik standartlar & 0 & $\% 0,0$ \\
Vizyon & 10 & $\% 45,4$ \\
Misyon & 11 & $\% 50,0$ \\
Kurumsal kültür ortalaması & 11,4 & $\% 51,8$ \\
\hline
\end{tabular}


Kurumların kendileri hakkındaki temel felsefesini yansıtan kurumsal kültür, şirket hakkında bilgi, temel değer ve politikalar, etik standartlar, vizyon ve misyonu içermektedir. Tablo 5'e göre; kuruluş hakkında bilgi \%100 ile tüm şirketlerin web sitelerinde yer almıştır. $\mathrm{Bu}$ bölümde çoğunlukla kuruluştan itibaren şirketlerin gelişimi ve kurucularından söz edilmektedir. Temel değer ve politikalar ise \%63,6 ile ikinci sırada gelmektedir. Etik standartlar ise \%0,0 ile bu bölümün en düşük ortalamasına sahiptir. Hiçbir şirketin web sayfasında etik standartlara ilişkin bir ifade bulunamamıştır. Şirketlerin açıklık, şeffaflıkla birlikte yönetişim durumunu da ortaya koyan etik standartların bu derece düşük çıkması şirketlerin kurumsallaşma ve küresel dünyaya ayak uydurma açısından standartlarını yükseltmeleri gerektiğinin birer göstergesidir. Şirketlerin vizyonları $\% 45,4$ oranında ve misyonları ise \%50,0 oranında web sayfalarına yansımıştır. Çalışmada yer alan şirketlerin ancak yarısının kurumsal kültür unsurlarına web sayfalarında yer verdikleri görülmüştür. Sonuçlar Mohammed vd. (2016) tarafından Hong Kong'da yapılan çalışma ile örtüşmektedir. Her iki çalışmada da şirketlerin ancak yarısı kurumsal kültürü web sayfalarına yansıtabilmiştir. Bu sonuçlar Baskan Karsak'ın (2008) çalışmasıyla örtüşse de oransal olarak düşük kalmaktadır. Baskan Karsak'ın çalışmasındaki şirketler kurumsal kültüre daha fazla önem verirken, bu çalışmadaki şirketlerin çoğunluğunun dijital dönüşüm konusunda yeteri kadar hızlı davranamadıkları görülmektedir.

Tablo 6. Web Sitelerindeki Kurumsal Davranışa Ait Unsurların Dağılımı

\begin{tabular}{lcc}
\hline \multicolumn{1}{c}{ Göstergeler } & Var (Sayı) & Var (Yüzde) \\
\hline Ekonomik bilgilendirme & 6 & $\% 27,3$ \\
Toplumsal bilgilendirme & 9 & $\% 40,9$ \\
Siyasi ve hukuki bilgilendirme & 0 & $\% 0$ \\
Kalite alanında bilgilendirme & 22 & $\% 95,5$ \\
İnsan kaynakları alanında bilgilendirme & 10 & $\% 45,5$ \\
Kurumsal davranış ortalaması & 9,4 & $\% 42,7$ \\
\hline
\end{tabular}

Kurumsal kimlik kavramının diğer bir ögesi şirketlerin iç ve dış hedef kitlelerine dönük davranışları olarak tanımlanabilecek kurumsal davranıştır. Kurumsal davranış bir yönüyle bilgilendirmeye dönük kurumsal iletişim faaliyetleridir.

Tablo 6'ya göre analiz edilen şirketlerin hedef kitlelerini ekonomik durumları açısından bilgilendirme oranları \%27,3'tür. Şirketler tarafından ekonomik bilgilendirme şirketlerin ancak altı tanesi tarafından, Konya Şeker, Eti Alüminyum, Panagro Tarım, Kombassan Kâğıt, Tümosan ve Konya Çimento tarafından yerine getirilmiştir. Söz konusu altı şirket ekonomik bilgilendirme faaliyetini web sitelerinin yatırımcı ilişkileri sekmesi yoluyla yapmaktadır. Diğer şirketler ise herhangi bir ekonomik bilgilendirmede bulunmamışlardır. Genelde sosyal sorumluluk ve sponsorluk gibi faaliyetleri içeren toplumsal bilgilendirme faaliyeti $\% 40,9$ gibi orta seviyelerde görülmüştür. Şirketlerle 
yüz yüze yapılan görüşmelerde sosyal sorumluluk adına yapılan birtakım faaliyetlerin hayırseverlik olarak değerlendirildiği ve toplumla paylaşılmak istenmediği öğrenilmiştir. Yine, şirketlerden hiçbirisi siyasi ve hukuki bilgilendirmede bulunmamıştır. Şirketlerin ürettikleri ürün ve hizmetlerle, işletmeye ve çalışanlara dönük uyguladıkları kalite standartları hakkında yaptıkları bilgilendirme \%95,5 ile çok yüksek seviyededir. Şirketlerin tamamına yakını, RTM Tarım hariç, kalite alanında bilgilendirmede bulunmuş, akreditasyon ve İSO belgelerini sayfalarına taşımıştır. Bu durum, şirketlerin, kalitenin hedef kitle üzerindeki etkisine önem verdiklerini göstermektedir. Mevcut ve potansiyel işgücüne dönük eğitim, kariyer, personel temini ve çalışan politikalarını içeren insan kaynakları alanındaki bilgilendirme ise \%45,5'tir. Yukarıdaki sonuçlar Baskan Karsak'ın (2008) çalışmasıyla kısmen örtüşmektedir. Söz konusu çalışmada ve bu çalışmada kalite alanındaki bilgilendirme yüksek oranda bulunmuş ancak siyasi ve hukuki bilgilendirme ise hiçbir şirket tarafından gerçekleştirilmemiştir. Ancak ekonomik bilgilendirme alanındaki farklılığın incelemeye tabi tutulan şirketlerin çoğunluğunun aile şirketi olmasından kaynaklanıp kaynaklanmadığı ise incelemeye ihtiyaç duyan bir konudur.

Tablo 7. Web Sitelerindeki Kurumsal Yapı Unsurlarına Ait Dağılım

\begin{tabular}{lcc}
\hline \multicolumn{1}{c}{ Göstergeler } & Var (Sayı) & Var (Yüzde) \\
\hline Kurum yöneticisinin mesajı & 3 & $\% 13,6$ \\
Organizasyon şeması & 1 & $\% 4,5$ \\
Üst yönetim kadrosu & 9 & $\% 40,9$ \\
Hizmet/ürün yapısı & 21 & $\% 95,5$ \\
Bayi/temsilcilik ağı & 11 & $\% 50,0$ \\
Kurumsal yapı ortalaması & 9,0 & $\% 40,9$ \\
\hline
\end{tabular}

Şirketlerin örgütsel durumunu ortaya koyan ve daha şeffaf olmalarına katk1 sağlayan kurumsal yapı unsurlarından hizmet/ürün yapısına $\% 95,5$ oran ile ilk sırada yer verilmiş, Akova Süt web sayfasında ise bu konuda bir bilgi bulunamamıştır. İkinci sırada bayi/temsilcilik ağına \%50,0 oranında yer verilmiştir. Söz konusu paylaşımlar kurumsal iletişim unsurlarından pazarlama ve satış odaklı içerik paylaşım sonuçlarını desteklemektedir. Yine üst yönetim kadrosuna $\% 40,9$ oranında yer verilirken organizasyon şemasına ise \%4,5 oran ile tek bir şirket, Eti Alüminyum kurumsal web sitesinde yer verilmiştir. Kurum yöneticisinin mesajı yalnızca Konya Şeker, Eti Alüminyum ve Atıker Makine şirketlerinin web sitelerinde kendine yer bulmuştur. Şirketler yapı, bayilik ağ ve üst yönetim kadroları konusunda yeterli bilgi vermeyerek şeffaflık açısından uygun davranmamış ve yeterli yönetişimi gösterememişlerdir. Yukarıdaki sonuçlar Koçer'in (2017) ve Muhammed vd.nin (2016) çalışmalarıyla kısmen benzerlik göstermektedir. Her üç çalışmada da organizasyon şeması yeterli oranda web sayfasına aktarılmamıştır. Bu durum şirketlerin kurumsallaşmaları konusunda alınması gereken çok mesafe olduğunu göstermektedir. 


\section{Sonuç}

İnternetin hayatın her alanına girmesiyle birlikte şirketlerin de interneti kullanması ve kurumsallaşmanın bir gereği olarak dijital dönüşümü sağlamaları gerekmektedir. Günümüz dünyasında her şirketin kurumsal kimlik bilgilerini web sitelerine taşımaları ve yine kurumsal kimliğe etki eden unsurları sosyal medya yoluyla hedef kitlelerine dönük olarak paylaşmaları beklenmektedir. Bu çalışmanın amacı, İSO'nun ilk ve ikinci 500 büyük şirket listesine girmiş olan Konya'daki şirketlerin kurumsal kimliklerini web sitelerinde nasıl yansıttıklarını değerlendirmektir. Çalışmada şirketler kurumsal kimliğin beş ana ögesi çerçevesinde analiz edilmiştir.

Bu çalışmada analiz edilen 22 şirketin yarıdan fazlası gıda şirketiyken diğer şirketler ise otomotiv, basım, ana metal, kimya, çimento ve plastik sanayi sektörlerinde faaliyet göstermektedir. Analiz edilen şirketlerin tamamının kurumsal web sitesi mevcut olmasına rağmen Akova Süt şirketinin kurumsal web sitesinin son bir iki ay içinde oluşturulduğu ve yeterli olmadığ1 görülmüştür.

Kurumsal kimliğin beş unsuruna göre yapılan analiz sonucunda; tüm unsurların ancak yüzde 50'ler seviyesi ve altında kaldığı görülmüştür. Kurumsal kültür unsuru diğer unsurlara göre web sitelerinde kendilerine daha fazla yer bulmuştur. Kurumsal kültürü sırasıyla kurumsal tasarım, kurumsal iletişim, kurumsal davranış ve kurumsal yapı unsurları takip etmiştir. Bu sıralama daha önce yapılan çalışmalarla kısmen örtüşmekte ancak yüzdelik oranlara göre düşük kalmaktadır. Konya'da analiz edilen şirketlerin çoğunluğunun aile şirketi olmasının yukarıdaki sonuçları doğurup doğurmadığı ise teyide muhtaç bir konudur.

Kurumsal kimliğin beş unsurundan biri olan kurumsal tasarım logo ve kurumsal renkler hariç yeterli görülmemiştir. Hiçbir şirkette logoya ait açıklamaları içeren kurumsal kimlik kılavuzunun bulunmaması manidar görülmüştür. Kalite alanında alınmış İSO belgelerini web sayfalarında gururla sergileyen şirketlerin ambalaj, reklam ve basılı materyal için ihtiyaç duyulacak kurumsal kimlik kılavuzlarını da bir an evvel oluşturarak web sitelerinde barındırmalarının yararlı olacağı düşünülmektedir.

Kurumsal iletişim unsurlarından şirketle ilgili iletişim bilgileri web sitelerinde yeterli olarak yer alırken, kurumsal imaj ve kurumsal itibara olumlu etkisi olan sosyal sorumluluk faaliyetleri yüzde 20'ler, sponsorluk faaliyetleri ise yüzde 5'ler seviyesinde kalmıştır. Şirket ve ürünlerin birbirine benzediği günümüzde kurumsal itibara çok büyük etkisi olan bu iki unsurun şirketlerin bütçeleri oranında hayata geçirilmesinde fayda görülmektedir.

Kurumsal kültür unsurları kuruluş hakkındaki bilgi hariç yetersiz seviyededir. $\mathrm{Bu}$ bölümde etik standartlar hiçbir şirkette bulunmazken şirketlerin kendileri hakkında ne düşündükleri konusunda çok önemli ipuçları veren vizyon ve misyon ise web sitelerinin ancak yarısında bulunmaktadır. Vizyonu olmayan ve var olma sebeplerini sayfalarına taşıyamayan şirketlerin sektörde uzun süre ayakta kalmalarının zor olacağ1 düşünülmektedir. 
Kurumsal davranış şirketlerin hedef kitlelerine dönük bilgilendirme konularını içermektedir. $\mathrm{Bu}$ bölümde kalite alanındaki bilgilendirmeler hariç, diğer bilgilendirme faaliyetleri yetersiz bir seviyede görülmüştür. Web sitelerinin hiçbirinde siyasi ve hukuki bilgilendirme bulunmaması ise benzer çalışmalarla örtüşen bir durum olarak incelenmeye değer bir husus olarak bulunmuştur.

Kurumsal yapı şirketin organizasyon yapısı ve yönetim kadrosu gibi önemli hususları içeren bir bölümdür. $\mathrm{Bu}$ bölümde organizasyon şemasının tek bir şirkette bulunması, yönetim kadrosuna yer veren şirket sayısının yüzde 40'lar seviyesinde kalması şirketlerin kendilerini ifade etmelerinde eksiklik olduğunun bir göstergesidir. Kurumsal yapının web sayfalarında bulunması, şirketlerin kendine olan güvenlerini ortaya koyarken aynı zamanda potansiyel işgücünün şirkete yönelmesine de katkı sağlayacaktır.

Küreselleşen dünyada kurumsal kimliğin kurumsal imaj ve devamında kurumsal itibar için vazgeçilmez bir araç olduğundan hareketle, kurumsal kimliğin önemi şirketlere bir kez daha anlatılmalıdır. Özellikle aile şirketlerinde kurumsallaşmanın çok zor olduğu, kurum kültürünün şirket sahibinin kültürüyle aynı anlamda algılandığı dikkate alındığında öncelikle şirketlerin üst düzey yönetici ve sahiplerine dönük eğitim verilmesine ihtiyaç duyulmaktadir.

Çalışma için kurumlarla iletişim geçildiğinde ${ }^{1}$ kurumsal web sayfası sorumluluğunun kimi şirketlerde bilgi işlem birimlerinde iken, kimi şirketlerde ise pazarlama/satış, muhasebe, kalite kontrol ve insan kaynakları birimlerinde olduğu görülmüştür. Kurumsal web sayfası sorumlusunun öncelikle kurumsal iletişim/pazarlama faaliyetleriyle bağlantılı kişilerden oluşturulması ve doğrudan şirket üst yönetimine bağlı olması şirketlerin kurumsallaşmaları açısından önemli katkılar sağlayacaktır.

\section{Kaynaklar}

Balmer, J. M. (1998). Corporate Identity and the Advent of Corporate Marketing. Journal of Marketing Management(14), 963-996.

Balmer, J. M. (2017). The Corporate Identity, Total Corporate Communication, Stakeholders' Attributed Identies, Identifications and Behaviours Continuum. European Journal of Marketing, 51(9/10), 1472-1502. doi:10.1108/EJM-07-2017-0448

Balta Peltekoğlu, F. (2016). Halkla İlişkiler Nedir? İstanbul: Beta Basım A.Ş.

Baskan Karsak, B. (2008). Web Sitelerinin Kurumsal Kimlik Açısından Değerlendirilmesi: En Beğenilen 20 Şirket Üzerine Bir Analiz. Galatasaray Üniversitesi İletişim Fakültesi Dergisi(9), 165-180.

1 Makalenin analizi yapıldıktan sonra 22 şirkete dönük bir çalışma başlatılmıştır. Çalışmada şirketlerin web sayfaları ve sosyal medyalarında kurumsal kimliğin unsurlarını takip etmek için gönüllü ikişer öğrenci görevlendirileceği ve dijital dönüşüme destek olunmak istendiği konusunda e-posta gönderilmiştir. Çağriya 22 şirketten dokuz şirket olumlu cevap vermiş ve Aralık 2020 itibariyle şirketlerin web sayfaları gönüllü öğrenciler tarafından takibe alınmıştır. Çalışma çerçevesinde örnek bir kurumsal web sayfasının yapımı da planlanmaktadır. 
Bravo, R., Chernatory, L., Matute, J., \& Pina, J. (2012). Projecting Banks Identities Through Corporate websites: Comparative Analysis of Spain and United Kingdom. Journal of Brand Management(20), 533-557.

Brotzen, D. (1999). The Role of Reputation in Crisis Management. London: Institute of Directors and AIG Europe.

Doğan, D. (2017). Fortune 500 Siralamasındaki Türk Havayolu Şirketlerine Ait Kurumsal Web Sitelerinin Kurum Kimliği Açısından Değerlendirilmesi. 3rd SCF International Conference on Economic and Social Impacts of Globalization (s. 183-191). Antalya: Uşak Üniversitesi.

Georgiadou, E., \& Nickerson, C. (2020). Exploring Strategic CSR Communication on UAE Banks Corporate Websites. Corporate Communications: An International Journal, 25(3), 413-428. doi:10.1108/CCIJ-02-2030-0044

Gray, E. R., \& Balmer, J. M. (1998). Managing Corporate Image and Corporate Reputation. Long Range Planning, 31(5), 695-702.

Gray, E. R., \& Semeltzer, L. R. (1985). Corporate Image: An Integral Part of Strategy. Sloan Management Review, 26(4), 73-78.

Huntington, S. P. (2014). Medeniyetler Çatışması ve Dünya Yeniden Kurulması. İstanbul: Okuyan Us Yayıncılık.

İSO. (2019). Türkiye’nin 500 Büyük Sanayi Kuruluşu. http://www.iso500.org.tr/ Erişim Tarihi: 20 Ekim 2020

Karaköse, T. (2007). Örgütlerde İtibar Yönetimi. Akademik Bakış(11), 1-12.

Koçer, S. (2017). Kurumsal Web Sitelerinin Kurum Kimliği Açısından İncelenmesi: En Çok Tercih Edilen Üniversiteler Üzerine Bir Analiz. Uluslararası Sosyal Araştırmalar Dergisi, 756-772.

KTO. (2019). Konya Ekonomi Raporu-2019. Konya: Konya Ticaret Odas1.

Melawer, T. C., \& Karaosmanoğlu, E. (2006). Seven Dimensions of Corporate Identity. Europan Journal of Marketing, 846-869.

Melawer, T. C., \& Saunders, J. (1998). Global Corporate Visual Identity System: Standardisation, Control and Benefits. International Marketing Review, 15(4), 291-308.

Melewar, T. C. (2003). Determinants of tehe Corporate Identıdy Construct: A Review of thte Literature. Journal of Marketing Communication, 9(4), 195-207.

Mert, Y. L. (2018). Siyasal Partilerde Kurumsal Kimlik Çalışmaları: Web Siteleri Üzerinden Bir Analiz. Akdeniz İletişim Dergisi(Haziran), 319-345.

Mohammed, İ., Denizci Guillet, B., Schuckert, M., \& Law, R. (2016). An Empiriccal Investigation of Corporate Identidy Communication on Hong Kong Hotels' Websites. Journal of Hospitality Marketing \& Management(25), 676-705. 
Morhard, J. E. (2010). Corporate Social Responsibility and Sustainability Reporting on the Internet. Business Strategy \& The Environment, 19(7), 436-452.

Okay, A. (2013). Kurum Kimliği. İstanbul: Derin Yayınları.

Okay, A., \& Okay, A. (2015). Halkla Iliş̧kiler Kavram Strateji ve Uygulamaları. İstanbul: Der Yayınları.

Olins, W. (2002). Viewpoints. Corporate Identity. The Ultimate Reseorce Business. https://docplayer.net/17101869-Wally-olins-viewpoints-corporate-identity-the-ultimateresource-business-2002.html Erişim Tarihi: 25 Kasım 2020.

Pant, G., \& Pant, S. (2018). Visbility of Corporate Websites: The role of Information Prosociality. Decision Support System(106), 119-129. doi:10.1016/j.dss.2017.12.006

Park, J., Lee, H., \& Hong, H. (2013). The Analysis of Self-Presentation of Fortune 500 Corporations in Corporate Web Sites. Business \& Society, 55(5), 706-737. doi:10.1177/0007650313512586

Sayımer, İ. (2012). Sanal Ortamda Halkla İlişkiler. İstanbul: Beta Basım A.Ş.

Schmidt, B. H. (1995). The Quest for Identity. London: Cassell.

TDK. (2020). Türkçe Sözlük. Türk Dil Kurumu Sözlük Web Sitesi: https://sozluk. gov.tr $/$ ?kelime $=\mathrm{k} \% \mathrm{C} 3 \% \mathrm{BClt} \% \mathrm{C} 3 \% \mathrm{BCrel} \% 20 \mathrm{kimlik}$. Erişim Tarihi: 19.01 .2020 